\title{
Cost effect of surgeon and patient discretion in regard to cataract surgery
}

This article was published in the following Dove Medical Press journal: Clinical Ophthalmology

\section{Tyler D Oostra' \\ Thomas F Mauger ${ }^{2}$}

'Havener Eye Institute, Department of Ophthalmology, The Ohio State University Wexner Medical Center, Columbus, OH 432I2, USA; ${ }^{2}$ West Virginia University Eye Institute, Department of Ophthalmology, West Virginia University, Morgantown, WV 26506, USA
Correspondence: Thomas F Mauger West Virginia University Eye Institute, Department of Ophthalmology, West Virginia University, I Medical Center Drive, Morgantown, WV 26506, USA Tel + I 68I 2850374

Email thomas.mauger@wvumedicine.org
Purpose: The purpose of this study is to examine the cost effect of surgeon and patient discretion in regard to cataract surgery and how this affects population health care costs.

Methods: A model of cataract progression was created from preexisting published data and combined with mortality data and Medicare cataract statistics to estimate the effect of mortality on decreasing the rate of cataract surgery if surgery was delayed until any cataract progression occurred.

Results: Five-year cataract progression rates were determined for a given patient age, sex, and type of cataract. Combined with 5-year death rates, delaying surgery until progression occurred resulted in a $1.1 \%$ decrease in surgery for nuclear sclerosis at age 45 that increased to a $33.8 \%$ decrease by age 90 ; a $1.5 \%$ decrease in surgery for cortical cataract at age 45 that increased to a $51.1 \%$ decrease by age 90 ; and a $1.6 \%$ decrease in surgery for posterior subcapsular at age 45 that increased to a $59.7 \%$ decrease by age 90 . The effect of this decrease in surgical volume on Medicare was estimated to result in a $13 \%$ overall decrease in cataract surgery annually at a cost of $\sim \$ 660$ million dollars per year.

Conclusion: Overall, we conclude that surgeon and patient discretion in regard to cataract surgery has a substantial cost effect with the potential to reduce surgical volume by as much as $13 \%$ by the decision to delay surgery as a result of patient mortality.

Keywords: cataract surgery, cataract progression, cost effect, health care costs

\section{Introduction}

The decision to pursue cataract surgery is a decision made by both the patient and surgeon in tandem. As cataract surgery techniques and outcomes have improved, patients have increasingly undergone surgery with better preoperative visual acuity and less severe cataracts. ${ }^{1}$ Accordingly, the rate of cataract surgery has dramatically increased. ${ }^{2}$ Due to a multitude of factors, patients and surgeons vary in regard to the degree of visual impairment at which the decision to pursue surgery is made. ${ }^{3,4}$ If a patient presents to a surgeon and the decision is made to delay surgery until the patient's cataracts worsen, then older patients may not survive long enough to see cataract progression and then undergo cataract surgery. This study aims to examine the cost effect of this decision from a health care population perspective taking into account previously published cataract rates of progression and mortality rates.

\section{Methods}

Published data on cataract progression from the Longitudinal Study of Cataract, ${ }^{5,6}$ the Beaver Dam Eye Study, ${ }^{7}$ and the Melbourne Visual Impairment Project ${ }^{8}$ were collected. These studies report rates of cataract progression for different age ranges among both males and females; the Longitudinal Study of Cataract and the Beaver Dam Eye Study 
report data for all three primary types of cataract, while the Melbourne Visual Impairment Project only reports data for nuclear sclerotic and cortical cataracts. The rates from these data sets were then combined to create a weighted statistical average of cataract progression rate based on cataract type, patient age, and sex. Actuarial life table data from the Social Security Administration were then used to determine population death rates for given patient ages and sexes. Five-year cataract progression rates and death rates were then combined to determine if patients would survive long enough to experience progression of their cataracts. The effect of mortality on decreasing the amount of cataract surgery performed for a given patient age and sex if surgery was delayed until progression occurred was thus estimated. Finally, these data were combined with Medicare cataract surgery statistics ${ }^{9}$ to estimate the cost effect of delaying surgery.

\section{Results}

Cataract surgery progression rates were calculated for both males and females from age 45 to 90 for nuclear sclerosis, cortical, and posterior subcapsular cataracts. For a male with nuclear sclerosis, the 5 -year rate of progression was found to increase from $33.9 \%$ at age 45 to $46.6 \%$ at age 90 . For a male with cortical cataract, the 5 -year rate of progression was found to increase from $12.6 \%$ at age 45 to $19.2 \%$ at age 90 . For a male with posterior subcapsular cataract, the 5-year rate of progression was found to increase from $2.4 \%$ at age 45 to $5.6 \%$ at age 90 . These data along with corresponding death rate data are presented in Figure 1. Similar data were determined for females as well but are not presented here. For males with nuclear sclerosis, it was calculated that the death rate would decrease the need for cataract surgery by $1.1 \%$ among 45 -year-olds and $33.8 \%$ among 90-year-olds as shown in Table 1. A similar effect occurred for cortical cataracts and posterior subcapsular, and these rates are shown in Table 1. Again, this effect was calculated for both sexes but not presented here. The overall effect of mortality on decreasing surgical volume for a given age is demonstrated in Figure 2. Using Medicare statistics of recent cataract surgery rates and patient demographic data, an overall decrease in surgery volume of $13 \%$ or $\sim 449,000$ surgical cases among Medicare beneficiaries annually would be expected by delaying surgery until cataract progression occurs. The approximate total cost effect to Medicare would be $\$ 660$ million dollars per year.

\section{Discussion}

Numerous studies have demonstrated the cost-effectiveness of cataract surgery. ${ }^{10,11}$ However, as the population ages,

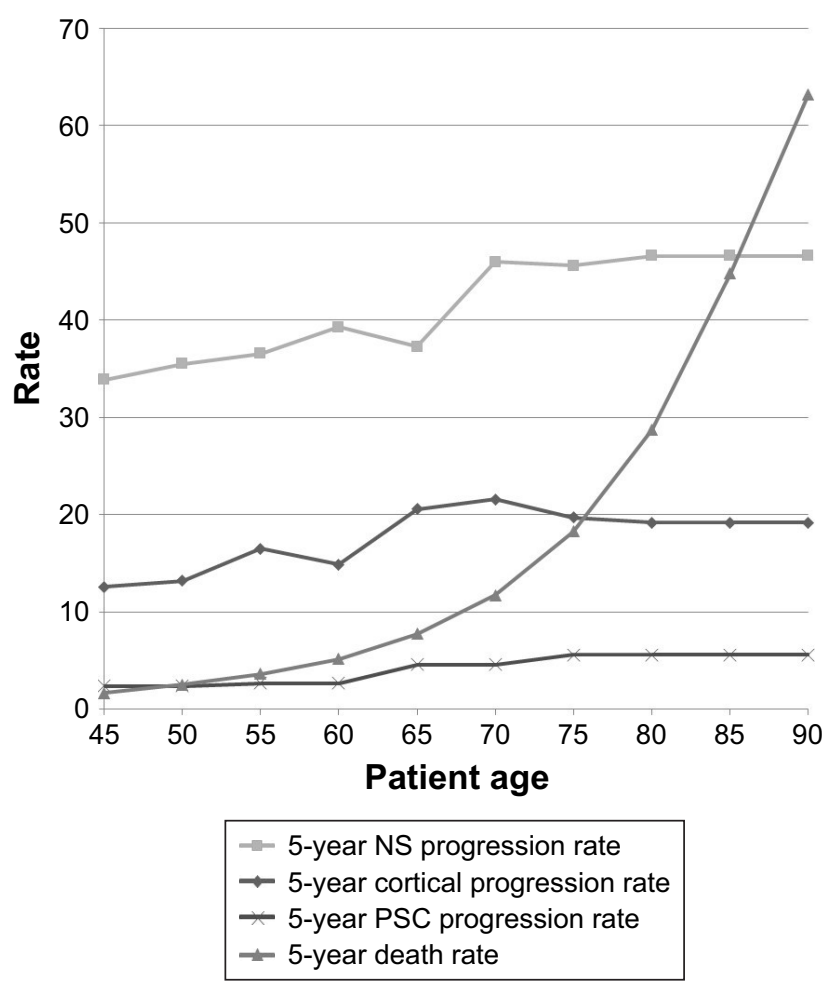

Figure I Cataract progression rate and death rate vs age among males. Abbreviations: NS, nuclear sclerosis; PSC, posterior subcapsular.

there is an ever increasing need to better utilize limited health care resources. The reimbursement model increasingly being pursued by Medicare is that of a population-based health care payment system as opposed to a fee for service system with the goal of decreasing health care spending. ${ }^{12}$ As the degree of visual impairment prior to surgery continues to decline and the rate of surgery continues to increase, ${ }^{1,2}$ surgeon and patient discretion regarding when to pursue surgery has the potential to have an increasingly significant effect on health care costs.

Table I Effect of mortality on decreasing surgical volume if surgery is delayed until progression occurs for different types of cataract among males at various ages

\begin{tabular}{|l|l|l|l|}
\hline Age & $\begin{array}{l}\text { Percent } \\
\text { decrease in } \\
\text { surgery for NS }\end{array}$ & $\begin{array}{l}\text { Percent decrease } \\
\text { in surgery for } \\
\text { cortical }\end{array}$ & $\begin{array}{l}\text { Percent } \\
\text { decrease in } \\
\text { surgery for PSC }\end{array}$ \\
\hline 45 & 1.1 & 1.5 & 1.6 \\
\hline 50 & 1.6 & 2.2 & 2.5 \\
\hline 55 & 2.3 & 3.0 & 3.5 \\
\hline 60 & 3.1 & 4.4 & 5.0 \\
\hline 65 & 4.9 & 6.2 & 7.4 \\
\hline 70 & 6.3 & 9.2 & 11.2 \\
\hline 75 & 9.9 & 14.7 & 17.3 \\
\hline 80 & 15.4 & 23.2 & 27.1 \\
\hline 85 & 23.9 & 36.2 & 42.3 \\
\hline 90 & 33.8 & 51.1 & 59.7 \\
\hline
\end{tabular}

Abbreviations: NS, nuclear sclerosis; PSC, posterior subcapsular. 


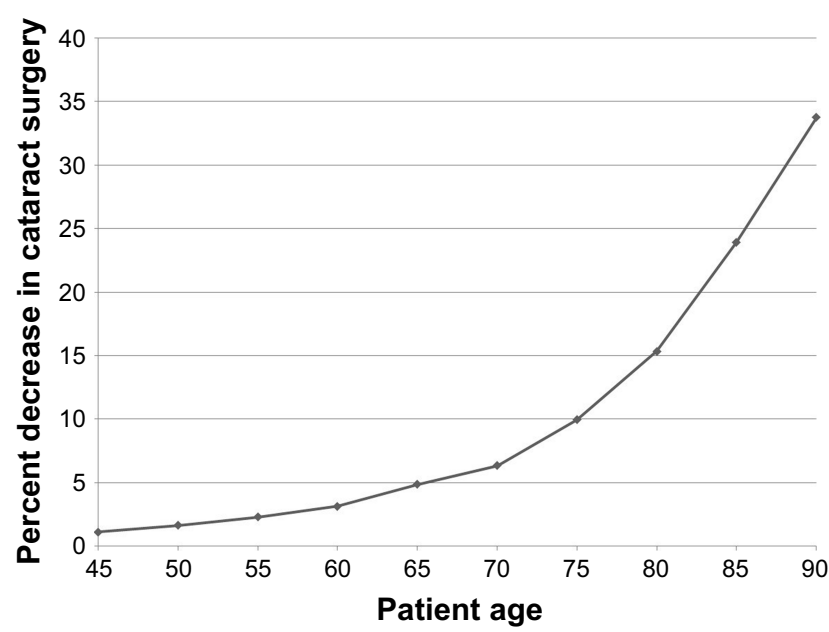

Figure 2 Estimated decrease in surgical volume vs age as a result of delaying surgery until cataract progression due to mortality.

As cataract is an age-related problem, our analysis suggests that a significant decrease in Medicare costs could be obtained by delaying surgery merely from the effect of overall patient mortality. This effect is estimated to result in as much as a $13 \%$ reduction in cataract surgery volume among Medicare beneficiaries in the United States on an annual basis.

Our analysis is limited by the type and quality of available cataract progression data. This progression model for cataract utilized lens change based on physical exam and photographs. Moreover, our analysis only looks at economic effects and does not address patient quality-of-life measures. Other studies have suggested that delays in cataract surgery may significantly increase overall patient disability. ${ }^{13}$

Overall, we conclude that surgeon and patient discretion in regard to cataract surgery has a substantial cost effect with the potential to reduce surgical volume by as much as
$13 \%$ by the decision to delay surgery as a result of patient mortality.

\section{Disclosure}

The authors report no conflicts of interest in this work.

\section{References}

1. Shapiro I, Shapiro MD, Wilcox DW. Measuring the value of cataract surgery. In: Cutler DM, Berndt ER, editors. Medical Care Output and Productivity. Chicago: NBER Books, National Bureau of Economic Research; 2001:411-438, Chapter 10.

2. Taylor HR. Cataract: how much surgery do we have to do? $\mathrm{Br} J$ Ophthalmol. 2000;84(1):1-2.

3. Mccarty CA, Keeffe JE, Taylor HR. The need for cataract surgery: projections based on lens opacity, visual acuity, and personal concern. Br J Ophthalmol. 1999;83(1):62-65.

4. Sletteberg O, Høvding G, Bertelsen T. Do we operate too many cataracts? Acta Ophthalmol Scand. 1995;73(1):77-80.

5. Leske MC, Chylack LT, Wu SY, et al. Incidence and progression of nuclear opacities in the Longitudinal Study of Cataract. Ophthalmology. 1996;103(5):705-712.

6. Leske MC, Chylack LT Jr, He Q, et al. Incidence and progression of cortical and posterior subcapsular opacities: the Longitudinal Study of Cataract. The LSC Group. Ophthalmology. 1997;104(12):1987-1993.

7. Klein BE, Klein R, Moss SE. Incident cataract surgery: the Beaver Dam eye study. Ophthalmology. 1997;104(4):573-580.

8. Mccarty CA, Mukesh BN, Dimitrov PN, Taylor HR. Incidence and progression of cataract in the Melbourne Visual Impairment Project. Am J Ophthalmol. 2003;136(1):10-17.

9. Schein OD, Cassard SD, Tielsch JM, Gower EW. Cataract surgery among Medicare beneficiaries. Ophthalmic Epidemiol. 2012;19(5):257-264.

10. Lansingh VC, Carter MJ, Martens M. Global cost-effectiveness of cataract surgery. Ophthalmology. 2007;114(9):1670-1678.

11. Brown GC, Brown MM, Menezes A, Busbee BG, Lieske HB, Lieske PA. Cataract surgery cost utility revisited in 2012: a new economic paradigm. Ophthalmology. 2013;120(12):2367-2376.

12. Centers for Medicare \& Medicaid Services. 2015 Face Sheets: Better Care, Smarter Spending, Healthier People: Paying Providers for Value, Not Volume. CMS.gov. 2015. Available from: https://www.cms.gov/ newsroom/fact-sheets/better-care-smarter-spending-healthier-peoplepaying-providers-value-not-volume. Accessed December 05, 2018.

13. Leinonen J, Laatikainen L. The decrease of visual acuity in cataract patients waiting for surgery. Acta Ophthalmol Scand. 1999;77(6): 681-684.
Clinical Ophthalmology

\section{Publish your work in this journal}

Clinical Ophthalmology is an international, peer-reviewed journal covering all subspecialties within ophthalmology. Key topics include: Optometry; Visual science; Pharmacology and drug therapy in eye diseases; Basic Sciences; Primary and Secondary eye care; Patient Safety and Quality of Care Improvements. This journal is indexed on

\section{Dovepress}

PubMed Central and CAS, and is the official journal of The Society of Clinical Ophthalmology (SCO). The manuscript management system is completely online and includes a very quick and fair peer-review system, which is all easy to use. Visit http://www.dovepress.com/ testimonials.php to read real quotes from published authors. 